\title{
Environmental consciousness amongst indigenous youth in Kenya: The role of the Sengwer religious tradition
}

\begin{tabular}{|c|c|}
\hline \multicolumn{2}{|c|}{$\begin{array}{l}\text { Authors: } \\
\text { King'asia Mamati }{ }^{1} \\
\text { Loreen Maseno }{ }^{2,3}\end{array}$} \\
\hline \multicolumn{2}{|c|}{$\begin{array}{l}\text { Affiliations: } \\
{ }^{1} \text { Department of Social and } \\
\text { Cultural Anthropology, } \\
\text { Faculty of Humanities, } \\
\text { University of Cologne, } \\
\text { Cologne, Germany }\end{array}$} \\
\hline \multicolumn{2}{|c|}{$\begin{array}{l}{ }^{2} \text { Department of New } \\
\text { Testament and Related } \\
\text { Literature, Faculty of } \\
\text { Theology and Religion, } \\
\text { University of Pretoria, } \\
\text { Pretoria, South Africa }\end{array}$} \\
\hline \multicolumn{2}{|c|}{$\begin{array}{l}{ }^{3} \text { Department of Religion, } \\
\text { Theology and Philosophy, } \\
\text { School of Arts and } \\
\text { Social Sciences, Maseno } \\
\text { University, Kisumu, Kenya }\end{array}$} \\
\hline \multicolumn{2}{|c|}{$\begin{array}{l}\text { Corresponding author: } \\
\text { King'asia Mamati, } \\
\text { mamatikingasia@gmail.com }\end{array}$} \\
\hline \multicolumn{2}{|c|}{$\begin{array}{l}\text { Received: } 04 \text { Apr. } 2021 \\
\text { Accepted: } 09 \text { July } 2021 \\
\text { Published: } 15 \text { Oct. } 2021\end{array}$} \\
\hline \multicolumn{2}{|c|}{$\begin{array}{l}\text { How to cite this article: } \\
\text { Mamati, K. \& Maseno, L., } \\
\text { 2021, 'Environmental } \\
\text { consciousness amongst } \\
\text { indigenous youth in Kenya: } \\
\text { The role of the Sengwer } \\
\text { religious tradition', HTS } \\
\text { Teologiese Studies/ } \\
\text { Theological Studies } \\
77(2) \text {, a6690. https://doi. } \\
\text { org/10.4102/hts.v77i2.6690 }\end{array}$} \\
\hline \multicolumn{2}{|c|}{$\begin{array}{l}\text { Copyright: } \\
\text { (c) 2021. The Authors. } \\
\text { Licensee: AOSIS. This work } \\
\text { is licensed under the } \\
\text { Creative Commons } \\
\text { Attribution License. }\end{array}$} \\
\hline \multicolumn{2}{|l|}{ Read online: } \\
\hline 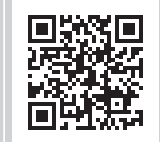 & $\begin{array}{l}\text { Scan this QR } \\
\text { code with your } \\
\text { smart phone or } \\
\text { mobile device } \\
\text { to read online. }\end{array}$ \\
\hline
\end{tabular}

Environmental destruction has contributed to climate change, a contemporary threat to the survival of the human race. Currently, many young people across the world are increasingly and actively involved in climate action, because of the realisation that climate change will disproportionately affect them. Kenya is adversely affected by climate change, with erratic and unpredictable rainfall patterns now being the norm. Given that the youth make up a large segment of the Kenyan population, they are well placed to contribute efficaciously to combating climate change. This article relied on both primary and secondary sources of data. Interviews, participant observations, focus group discussions, articles, books and archival material were used to generate data. Purposive and snowball sampling techniques were used to get key informants. Data were analysed thematically as per the topic under study. The article focuses on how the Sengwer indigenous community created environmental awareness and utilised their epistemological approaches to ensure a conscious mindset amongst the youth on the sustainability of the environment. In this article, we argue that the complex social systems that have religious underpinnings in traditional society play a critical role in ensuring that young people are environmentally conscious. Religion facilitates knowledge acquisition amongst the youth and shapes their understanding and consciousness of the environment. The findings indicate that indigenous communities had an effective system of ensuring that young people are conscious of their environment.

Contribution: This article seeks to contribute to an instauration of indigenous knowledges and epistemologies on environmental issues. It proffers for a holistic approach of incorporating indigenous ways of creating environmental consciousness and awareness amongst the youth.

Keywords: religion; environment; African traditions; conservation; Sengwer; indigenous youths; indigenous epistemologies; youth consciousness.

\section{Introduction}

It is indubitable that the world today is facing an enormous threat to the survival of humanity. The environmental crisis has social, political, and economic ramifications that affect all groups in society. Currently, many young people across the world are increasingly and actively involved in sustainable climate action, because of the realisation that climate change will disproportionately affect them (Wu, Snell \& Samji 2020). The unpredictable weather pattern has led to extreme events. Floods, landslides, and droughts are now the norm in Kenya as well as in many other countries.

As the world grapples with climate change, many young people across the world more specifically in Europe and close to 100 other countries have taken to the streets to protest. The 18-year-old Swedish climate activist Greta Thunberg has popularised the school strike for climate. The young voices that have joined youth for climate have raised concern over the impact of climate change on their future lives (Lee et al. 2020). The youth have also voiced plangent environmental concerns over the slow action being taken to curb global warming.

Kenyan youth make up the biggest segment of the Kenyan population. According to the 2019 Kenyan population and census report, $75.1 \%$ of the 47.6 million population is under the age of 35 (Kenya National Bureau of Statistics [KNBS] 2019). The youth have the potential and power that has not yet been tapped to drive the environment conservation agenda and climate

Note: Special Collection: Youth, Faith, Climate Change and Environmental Consciousness: A Case for Sustainable Development, sub-edited by Jacques Beukes (University of Pretoria), Juliane Stork (Humboldt University, Berlin) and Ignatius Swart (University of the Western Cape) 
change sensitisation in Kenya. On the contrary, many young people have been plagued by poverty, unemployment, teenage pregnancies, drug abuse, drug trafficking and many other social ills. The above-mentioned situations have led many youths to be concerned with their survival amidst the harsh economic times that have estranged and precluded them from being conscious of the environment.

The adoption of the modern lifestyle has contributed to the current environmental crisis as people embrace an unsustainable lifestyle that threatens the basic life support systems. The ever-increasing population is putting more pressure on finite natural resources. The economic interest has led many people to destroy the forest and establish farms for agriculture. Industries have emitted poisonous substances into the atmosphere and water bodies such as lakes and rivers. Besides, riparian lands have been encroached on for economic gain. The aforesaid facts clearly show a breakdown of the traditional African setup and institutions that were assiduous in the welfare and well-being of the environment and every member of the society.

It is important to note that the Sengwer community is amongst one of the most vulnerable and marginalised communities in Kenya. They face a myriad of challenges and have been subjected to innumerable evictions from their ancestral land (Mamati 2018:41-50), leaving them in a precarious and beleaguered situation. The evictions have a toll effect on the overall health of the Sengwer people, especially women and children who carry the brunt of the evictions, being vulnerable to diseases, losing their breadwinners, family separation and early marriages. Besides being physically tortured and sexually molested, they are also tormented psychologically (Chepkorir 2016: 5-12). Moreover, their identity as an indigenous forage community, and their environmental knowledge, culture and religion are on the fringes of being extirpated. This is because of ecologically induced genocide to this particular community that threatens their social, cultural and physical existence (Crook \& Short 2020). This clearly shows that environmental conservation measures and climate change mitigation are enshrouded in colonial and post-colonial thought that casts aside important traditional environmental knowledge. Ngugi wa Thiong'o (1986) aptly pointed out how colonial systems suppressed, undermined, undervalued and destroyed indigenous knowledge rooted in diverse cultures. Colonial systems alienated the child from his culture by disassociation of the sensibility of the child from the natural and social environments (Thiong'o 1986:16). This blatant disregard of African indigenous knowledge issues have led to what Ndlovu-Gatsheni (2018:106) has termed 'epistemicide', which is a condemnation, destruction and replacement of preexisting knowledge systems. Furthermore, it also led to demonisation and marginalisation of indigenous practices by missionary and colonial forces (Maathai 2010:71; Ikuenobe 2014:13), resulting in desacralisation of the environment and landscape as people started commodifying nature.

Many contemporary programs developed by the Kenyan government and non-governmental organisations that seek to intervene and create awareness of the ubiquitous environmental crisis have often neglected indigenous ways of creating environmental consciousness amongst the youth. Wane (2005:28) noted that 'local knowledge "in this regard environmental knowledge" of African people are least analysed, considered or understood for their contributions' especially in providing alternatives ways of sensitising the youth on environmental issues. This article highlights the complex epistemologies coupled with an intrinsic religious system used by the Sengwer to equip young people to make them conscious of their environment. The all-inclusive social systems that have religious underpinnings in traditional society play a critical role in ensuring that young people are environmentally conscious. Religion facilitates environmental knowledge acquisition amongst the youth and shapes their understanding and consciousness of the environment. This article aims to lead to an instauration of indigenous knowledge and epistemologies on environmental issues.

\section{Method}

This qualitative study was descriptive and explorative in nature, focusing on the Sengwer people within Cherangany water catchment area. Because of the nature of the study, the article relied on participant information from key informants amongst the Sengwer people which included Sengwer elders, rainmakers and herbalists. Purposive and snowball sampling methods were used to get informants for the study.

Primary methods of data collection for this research article included personal interviews, participant observations and focus group discussions. Secondary data were obtained from archival documents from Kenya National Archives, books and articles. Data were analysed thematically and collaborated with the published literature on Sengwer community.

\section{The Sengwer indigenous people}

The Sengwer people are an ethnic minority who are traditionally hunter-gatherer people. They are a distinct ethnic group as noted by Arap Kamussein, a Sengwer chief 'we are not Marakwet, but Sengwer' (Kenya Land Commission 1934). Their ancestral lands are located in parts of Elgeyo Marakwet, parts of Pokot, Trans Nzoia counties in Kenya, in and around the forests of the Cherang'any Hills. In a letter by the assistant district commission to the provincial commissioner from 01 October 1918, he refers to the Sengwer as a 'minority, unrecognized, marginalised, oppressed and discriminated hunter-gatherer indigenous group' (Kenya National Archives [KNA]). Regrettably, they are still characterised as an indigenous marginalised, oppressed, and discriminated community. This is evident in the forced displacements and sustained evictions of this community from the forest by the Government of Kenya through the support of now suspended European Union and the World Bank-funded projects aimed at mitigating climate change (Cavanagh 2019; Crook \& Short 2020; Mamati 2018; Yator 2016). Evidently, the basic human rights of the Sengwer community as enshrined in chapter four of the Bill of Rights 
in the 2010 Kenyan Constitution, have been continuously violated through the sustained evictions.

They are also referred to as the Cherangany, a name used interchangeably with the name Sengwer. The appellative Cherangany was given to them by the Masai to deprecate their hunting and gathering lifestyle and their lack of animals. This is buttressed by the District commissioner's yearly report in Tambach on 11 October 1927 that states: 'We were robbed of our cattle by the Karamojong and then the Maasai laughed at us because we had no cattle, and called us Cherangany' (Kenya Land Commission 1934).

They were also nicknamed Dorobo, which means people whose livelihood wholly depends on hunting, gathering and beekeeping. This is after the neighbouring communities took their cattle which they had obtained from banter exchange by trading honey, medicine, iron, bowls and arrows in exchange for cattle (Kibet pers. comm., 16 November 2016). Blackburn, an early ethnographer who carried out extensive research amongst the OKiek of Mau notes that Dorobo was a generic term referring to a hunter-gatherer group (Blackburn 1970). It was also a term used by the Maa speaking group to refer to the hunter and gatherer groups.

The Sengwer community has been recognised as indigenous aboriginals inhabiting Cherangany Hills since the 18th century by a Parliamentary Select Committee Report on the Resettlement of the Internally Displaced Persons in Kenya. The Committee stated (Kenya National Assembly [PSC] 2012):

The Sengwer also referred to as Kimala are the indigenous people of Embobut scattered all over Embobut forest. There are one thousand five hundred and forty-six (1546) households of the Sengwer people in Embobut forest. The Embobut community had lived in the forest since the 18th century and the land they occupied was their ancestral land and even after the coming of the colonial government, they were issued with permits to continue living in the land. (pp. 40-41)

Figure 1 shows the location of the Embobut in Elgeyo Marakwet County.

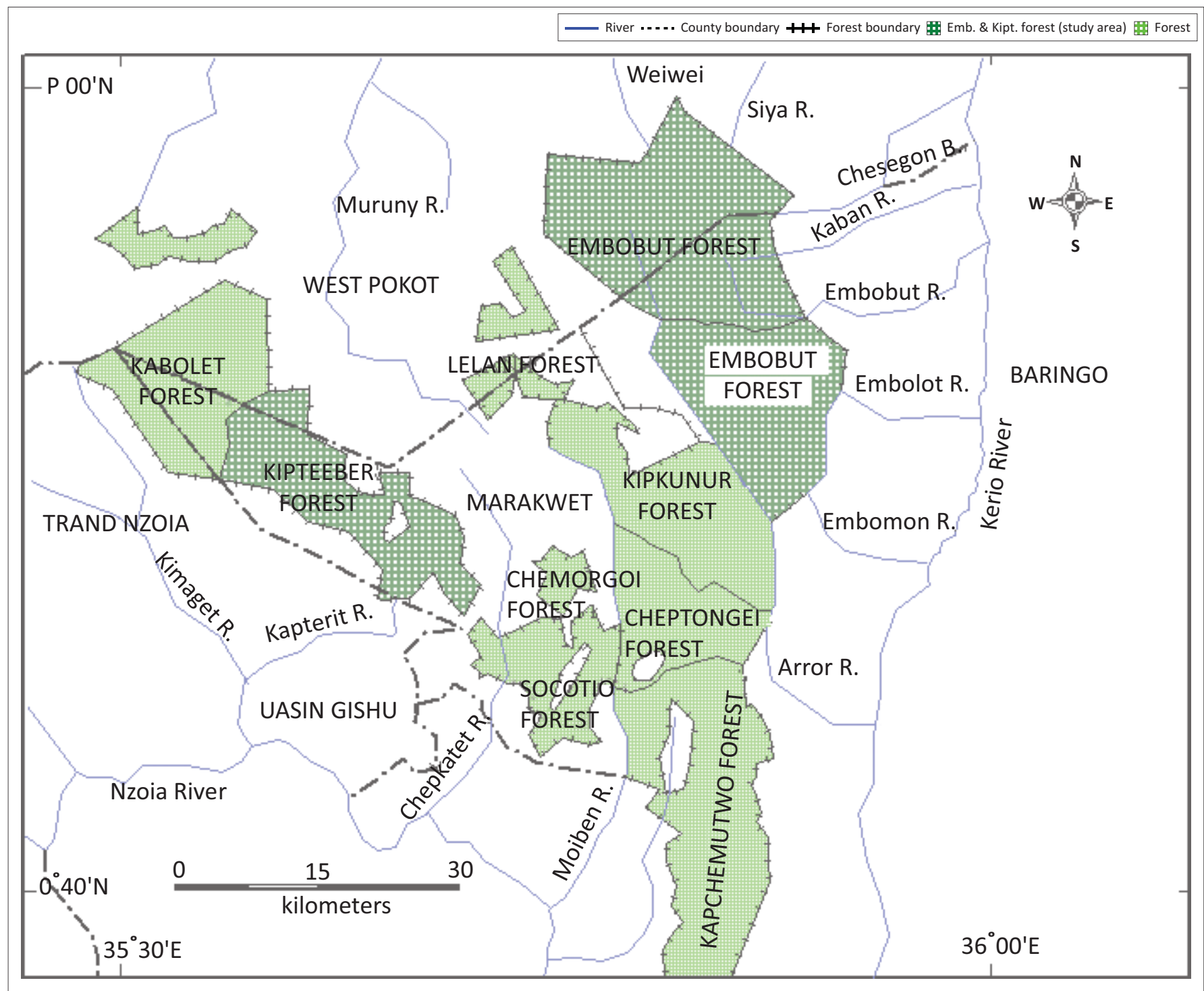

Source: Mr Kanda, Moi University cartography.

FIGURE 1: Map of Cherangani hills. 
The Sengwer are also part of the larger Ogiek groups. Blackburn (1970) succinctly describes the Ogiek as:

$[O]$ ne of the most widely distributed tribes in Kenya, inhabiting, now or in the recent past, virtually all of the high forest areas of Kenya. Traditionally they are a hunting and gathering tribe. (p. 3)

Despite belonging to the larger Ogiek group, they have their defined distinct way of life and religious system that was influenced by their interactions with the environment and to some extent by contact with their neighbouring ethnic communities.

\section{Indigenous religion as a basis for environmental concern}

Religion is an integral part of many African societies especially those found in sub-Saharan. Mbiti (1975) succinctly averred that:

Africans are notoriously religious, and each people has its own religious system with a set of beliefs and practices. Religion permeates into all the departments of life so fully that it is not easy or possible always to isolate it. (p. 1)

Religion forms the basis of all human interaction with their environment. The religious worldview of the Sengwer influences their action and behaviour towards the environment. They believe in a supreme being called Assis. Assis is charged with the creation of the universe and all the natural resources in it, who is omnipotent and omniscient (Kipkorir 1976; Kipkorir \& Welbourn 1973:14; Mamati 2018). It is viewed that, participating in natural environment conservation, and taking care of natural environmental resources is a way of fulfilling gratitude to the supernatural being and the spiritual world. During the research, it was noted that the Sengwer do not have a conclusive story of how the creation of the earth was done. A similar situation is also seen amongst Marakwet who have no story of creation (Kipkorir \& Welbourn 1973:34). The Sengwer religious systems are closely related to the Marakwet and Pokot religious thought because of their close proximity with them as a result of a long history of interactions and inter-marriages. The Sengwer believe that Assis created their first ancestor called Sengwer, who directed them to the forests and the lowlands (Mamati 2018:34).

The research participants argued that the young people are taught that the sun is the eye of Assis who sees everyone and most of the community activities were done during the daytime. This meant that they were to be conscious of their actions and behaviour, for the eye of God was seeing them. Assis' command is expected to be obeyed by everyone or else he will punish those who go against his teachings through his personalities on earth such as his chief divine agent Illat the elders, herbalists, rainmakers, amongst others. Therefore, it is mandatory for everybody to observe the laws of Assis on natural environment conservation handed down through the specialists. All prayers are directed to Assis through his chief agent Illat. The Sengwer made it a tradition by praying thrice a day - in the morning, at noon and in the evening. Apart from daily prayers, they prayed for blessings before hunting, for protection and healing.

Illat is a chief divine agent of God that appears in the form of thunder and lightning. He is also referred to as the god of rain or the god of thunder as these were some of the forms of his manifestation (Kipkorir \& Welbourn 1973). Illat acts as an intermediary between God and the Sengwer community. Mbiti (1969:65-66) postulates that Africans held the view that God specifically created the spirits and divinities to act as intermediaries between him and men. The Sengwer offered sacrifices and prayers to God through Illat by invoking the spirits through the use of natural resources found within their environment to appease the spirits. Illat being the chief agent was responsible for accepting or rejecting the sacrifices (Mamati 2018:36).

The Sengwer revered and venerated spirits especially ancestral spirits. The belief in ancestors is in and of itself connected to the Sengwer religion. According to Orobator (2008), an ancestor is a blood relative of a living community whose relationship could be of common parentage or shared ancestry. The belief in ancestors is linked to the community's close attachment to the forest because they believe that the ancestral spirits live in the forest. This motivated the Sengwer to conserve the forest and the natural environmental resources (Mamati 2018:37).

The Sengwer religion acknowledges that creation does not belong to us but to God (Assis). By recognising God's ownership, their indigenous religion treats the earth and its natural resources with reverence. Thus, it is transformed into a bearer of life. Environment conservation, therefore, is regarded as a sacred duty by the Sengwer because it is the nexus in the relationship with Assis. Thus, according to them, the spiritual world and the physical world are indivisible. The numinous belief about the earth formed the basis of the human relation and interactions with the physical world.

The complex religious system of the Sengwer formed their worldview and their knowledge of nature, the physical world and all its surrounding (Mamati 2018:40). The youth were taught about the interrelatedness of the human community and the non-human community. This means that the living, the non-living, the unborn, the ancestors, the spiritual beings and God are related to the environment (Terekoi, pers. comm., 15 November 2016). Amongst the Sengwer community, it is the human beings who are regarded as the paragon of God's creation. They are the greatest beneficiaries of the ecosystems as they heavily 
depend on it. Human beings are at the centre of the visible world and the invisible world. This understanding underscores the need for the Sengwer youth to live in harmony with the natural resources. For this to be achieved, the community used different epistemological approaches to teach the youth about the need to fortify an equilibrium relationship of dependence on the nature.

\section{Sengwer epistemological approaches to environmental consciousness}

Rowlands (2005:20-25) defines environmental epistemologies as the adequacy of cognitive operations through environmental cues that aid memory by which individuals find about their natural environment and the degree of cohesion that results between the world and the operations. The natural environment contains important structures of relevant information that can be used to accomplish a given task and that can be appropriated by individuals and communities towards a particular goal. Epistemological approaches to environmental consciousness here refer to disparate all-encompassing indigenous ecological knowledge that was passed down to youth amongst the Sengwer community. The knowledge or the consciousness arises locally through a long-term interaction of a community with its environment (Wane 2005).

Berkes, Colding and Folke (2000) have aptly defined:

[T]raditional ecological knowledge as a cumulative body of knowledge, practice, and belief, evolving by adaptive processes and handed down through generations by cultural transmission, about the relationship of living beings (including humans) with one another and with their environment. (p. 1252)

This kind of knowledge is neither static nor backward, but it is adaptive to the changes. Similarly, Semali and Kincheloe (1999:3) expounded that indigenous knowledge reflects the dynamic way in which the local people understand themselves in relation to their natural environment as well as how they organise that folk knowledge of flora and fauna, cultural beliefs and history to enhance their lives.

\section{According to UNESCO (2017):}

Local and indigenous knowledge refers to the understandings, skills, and philosophies developed by societies with long histories of interaction with their natural surroundings. For rural and indigenous peoples, local knowledge informs decision-making about fundamental aspects of day-to-day life. This knowledge is integral to a cultural complex that also encompasses language, systems of classification, resource use practices, social interactions, ritual, and spirituality. (p. 9)

Nesterova and Jackson (2020:1) have referred to this type of impacting knowledge as 'ecopedagogy', which is teaching and learning that embraces a biocentric approach that questions the structures, and power relations deemed destructive to the Earth. Ecopedagogy values all organism and non-organism systems such as landscapes as being critical to earth rehabilitation.

Environmental consciousness is based on indigenous environmental knowledge and education that is carried forth from one generation to another. Education that resonates well with people's culture and their local cultural context is an efficient way of ensuring that environmental sustainability is achieved. Ezeanya-Esiobu (2019) notes that for education to advance society, it must be relevant to the needs of the people concerned and be appropriate to the social and material environments in which it is pursued.

The Sengwer have a symbiotic and mutual relationship with their environment. The destruction of the forest and natural resources threatens the community's existence and wellbeing. To safeguard their well-being, they are tasked to ensure that the forest and the resources found within their jurisdiction are used sustainably. More importantly, they have a holistic environmental knowledge that is passed on from generation to generation. This important ecological knowledge is on the verge of being forgotten because of cultural changes. It is therefore imperative to highlight different epistemological approaches that they utilise to ensure environmental consciousness amongst young people of the Sengwer community.

Sacred places are more respected and revered because it is believed that divine as well as ancestral spirits resided there. Sacred places in Embobut forest include water bodies such as rivers, streams and hills that were considered to be closer to God and his agent, Illat. Kiptaberr Hill is a legendary hill believed to be inhabited by spirits. Waterfalls and rivers such as the River Embolut, River Kapolet, River Ainakog and caves are sites for religious and cultural continuum. The land and the forest are largely viewed as ancestral habitation. Members of the Sengwer tribe paid homage to the ancestors by living sustainably with the environment through efficient sustainable use of environmental resources handed to them by their ancestors. There are proscriptions on their interactions with the sacred through taboos and totems as it shall be discussed in the succeeding section.

The Sengwer performed various rituals at the riverside; they held the belief that Illat, the chief agent of God (Assis) resided along the rivers and water streams. River confluence is believed to be the home for Illat family (Kemboi, pers. comm., 20 November 2016). In this regard, rivers and water streams were significant to the Sengwer community. They depend on these rivers to appease divine deities, especially Illat. During the dry periods, the Kaptoyo clan whose totem is lighting (the clan in charge of rainmaking) went to the river confluence to perform rituals and beseech the divine being to release rain (Mamati 2020:304-305). The rain would later lead to the flowering of plants, which in turn provide plenty of honey. The youth were taught about the importance of rivers to the community. Not only did the Sengwer rely on these rivers for drinking water but also for honey as bees depended on these rivers for water, pollination and honey production. 
To safeguard the sacred sites such as rivers, hills and caves against pollution and human interferences, the community has taboos on all sacred sites found within their locality. For instance, the Sengwer young people are not supposed to defecate in rivers nor to bathe in small streams of water, as this would cause the wrath of Illat, the rain spirit, to come down upon that person or the community (Mamati 2020:304). Young people are not supposed to interfere with natural resources, such as trees or stones found within rivers, because it is believed that the family of Illat resides there. These beliefs in deities that inhabited sacred sites such as hills, rivers and streams of water made the young people grow up with a high degree of reverence to all the sacred sites found within their locality. Thus, they treat rivers and water bodies with a high reverence. The young people grew up with an environmentally conscious mindset regarding rivers, streams and water bodies. The consequences for going against the community's rules concerning water bodies would result in somebody being struck by Illat in the form of lightning (Mamati 2018, 2020:305).

Embobut forest and Cherangany water catchment area at large has a wide variety of flora. The resources found in the forest are of significance to the Sengwer people because their main livelihood depends on them. The forest is significant for medicinal value, hunting, and gathering, and honey making. Trees and plants found in the forest are also used for ritual purposes and are regarded as sacred (Rotich, pers. comm., 16 November 2016). There is a general belief that all the trees are imbued with spirits. Whenever a tree is cut, the liquid that oozes out of it, according to this community, means the spirits are crying (Terekoi, pers. comm., 16 November 2016). Young people are taught about the need to ensure that spirits do not get angered, lest the wrath of the supreme being and the ancestors befell the community. Young people are taught that it is only the clan Elders who have the mandate of harvesting trees for a particular social and religious purpose. Only a few branches were harvested from a single tree.

The socio-environmental identity of the youth amongst the Sengwer was based on a continuous life learning process from childhood until adulthood and lastly in transition to the ancestral world. Parents had an elementary responsibility of ensuring that important ecological knowledge was passed on to their children. Kibet, a Sengwer elder (pers. comm., 17 November 2016), posited that 'as a hunter gather community, we had well defined gender roles, everybody knew their responsibility in relation to the sustainable usage of natural environmental resources'. He further explained that the mothers taught their daughters about appropriate and sustainable ways of gathering fruits and vegetables in the forest whilst the fathers taught their sons about sustainable hunting practices. Young girls only collected dead woods for firewood. Young boys were taught how to mend beehives sustainably. Parents also ensured that young people grew up knowing their totemic animal. Totems played a significant role in conserving a wide variety of animals and birds. A similar comparison has been made amongst the Ogiek of Kenya where it has been observed that in Africa using these forested places of protective spirit, resources for ecological justice have been enumerated to the end of a more just relationship to the whole inhabited earth (Maseno 2020).

Collective responsibility is emphasised by parents and elders in the society. Women and girls would gather fruits and vegetables as a group, likewise, men and boys went hunting as a group. Whenever hunters made a kill, they would share the hunted animal, however small it was, and regardless of the number of hunters (Mamati 2018:40). Sakas (collective hunting) demonstrates the Sengwer emphasis on communalism amongst young people. This norm extended to natural environmental conservation as young people grew up knowing that they belonged to the community, and they are the community that was given the mandate by God to be the custodians of the natural environmental resources. Every member of the community is tasked to be always concerned about others. Young people are taught about the value of communalism and individualism was highly discouraged as illustrated by collective hunting and gathering.

Initiation rites of passage locally referred by the Sengwer as Kibuno is one of the biggest ceremonies that is revered by all members of the community (Kimaiyo, pers. comm., 28 June 2020). It lasts for a whole month every end of the year where initiates stay in the forest at a designated sacred site before being incorporated into the society. The culmination of raising an environmentally conscious youth occurs during the initiation rites of passage. The secluded sacred sites act as a classroom for passing important environmental knowledge to the graduating age set. The youths are reminded of environmental knowledge relating to animals, birds, hills, caves, snakes, birds, trees, taboos and totems. Insistence is placed on the special relationship between the Sengwer community and their environment. Social, religious, cultural, economic and environmental responsibilities are officially bestowed on to this age set group. The graduating youth are empowered with all the required knowledge to be conscious of their behavior and interaction with the environment. They teach the youth about their age sets, the community's expectations and different natural resources, such as the flora and fauna found in the forest and sustainable utilisation of these resources (Mamati 2020:306).

The initiation rites of passage at the sacred sites bind the initiates with the ancestors. It connects them to the spiritual realm of the ancestors. The research participants averred that the blood that drops on the ground during the circumcision of young men acts as a covenant between the initiates and the ancestors. The initiates are obliged to live and abide as per the expectations of God, the ancestors and the council of elders. Failure to observe the community rules and regulations attracted the wrath of the ancestors. In most cases, such a person would be struck by lightning through Illat or banished from the community by the elders. 
Prospective young herbalists are identified at a tender age by the community herbalist who hailed from their families. Herbalists were tasked with teaching the prospective young herbalist different ways of harvesting and sustainably extracting plant products. Harvesting of medicine was only limited to the herbalist for efficacy. The wide variety of medicinal products found in Cherangany are used traditionally to treat different ailments such as snake poisoning, stomach upsets, menstrual complications, headaches and so on (Chebet \& Talam, pers. comm., 28 August 2016).

Table 1 shows the medicinal values of some of the trees and plants.

Traditional herbalists were willing to divulge a handful of their traditional herbal medicine. Nevertheless, ethnomedicinal studies done in this region reveals that the region has a great medicinal plant diversity. Morara Mbuni et al. (2019) have documented an annotated checklist of vascular plants found in this region.

Young people are taught about the various animals found within the forest. The forest had various species of animals that were at the centre of the Sengwer life because they depended wholly on hunting these animals for their livelihoods. Kirui (pers. comm., 25 August 2016) notes that animals such as buffaloes (soo) and elephants (pelit) are viewed as a sign of blessings. They hunted animals such as antelopes and rabbits whilst animals such as Columbus monkey and wild goat provided materials for making ritual garments under the guidance of the elders. The community through clan elders advocated for efficient sustainable hunting practices of the animals to avoid some animals facing extinction. This was done through various beliefs and practices such as taboos and totems that were held and attached to various animal species by the Sengwer people.

The youth are exposed to an array of beliefs and taboos associated with animals and regulations on animal product use. Even though some animal skin such as skins from the wild goat and Columbus monkey are used to make ceremonial garments, they are made in a sustainable way guided by the community council of elders that do not threaten the extinction of Columbus Monkey or any other animals. Mamati (2020:297-299) has done an extensive study on the taboos that relates to various aspects of the environment

TABLE 1: Medicinal values of some of the trees and plants.

\begin{tabular}{lll}
\hline Traditional name & Scientific name & Medicinal value \\
\hline Cheptuya & Euclea divinorum & Treats worms \\
Lobcho & Dryopteris inaequalis & - \\
Cheptegaa & Yushania alpina & Reduces acid in the body \\
Mindilililwo & Dovyalis abyssinica & $\begin{array}{l}\text { Treats STD } \\
\text { Treats barrenness }\end{array}$ \\
Eboria & Unknown 3 & Treats STDs \\
\hline
\end{tabular}

Source: Chebet, pers. comm., 24 November 2016

STD, sexually transmitted diseases. amongst the Sengwer community. These taboos, coupled with their religious worldview helped in the conservation of different aspects of environmental resources found in Embobut forest. Likewise, there exists extensive scholarly work on how different communities in Africa have used taboos to ensure the conservation of environmental resources. Amongst the Sankana and Tongo-Tengzuk communities in Ghana, totems and taboos play a role in the conservation of natural resources (Diawuo \& Issifu 2018). Taboos are a source of environmental ethics amongst the Shona (Chemhuru \& Masaka 2010). Totems, taboos and sacred places amongst the Karanga people are a source of environmental preservation models and mechanism (Makamure \& Chimininge 2015). The Sengwer people use taboos and totems to foster an environmentally conscious mindset amongst the youth. Young people are taught about their totemic animals, birds, insects or objects which they are expected to treat with high degree of reverence and respect. The totems are an emblem of the community's history, origin and survival. Kibet and Kibichii (pers. comm., 28 August 2016) argue that:

Totems are important to our culture because of the special connection and history that each clan has to its particular totem. We teach our children about their totems and how to interact their totemic animal.

Each clan has its own totem. Parents as well as members of a particular clan have a duty to teach children about their totem and the story behind the clan's totem, and the role the totem played in the clan's history. For example, the Moi clan's totem is buffalo (Soo), the totem of the Kaptoyoi clan is lightning (Illat) and the totem for the Saniak clan is prech [safari ants] and chereer [monkey]. For the Kapon clan, the totem is morooroch nyipo pei [frog], morooroch nyipo sang [toad], and cheplaanga [leopard] (Kimaiyo, pers. comm., 20 August 2021).

In this regard, young people are taught about their totems, taboos concerning their totems and how to behave in order to honour their totems which is tantamount to venerating the ancestors. Thus, these gave the young people a sense of belonging and an attachment to their various totems.

\section{Communicating environmental knowledge}

The traditional societies in Africa, in particular, the Sengwer have repertoires of oral literature that act as a basis for creating and communicating environmental consciousness amongst young people. Oral literature is the foundation upon which transmission of traditional knowledge and religion are built on. They employed various forms of oral literature to ensure that environmental knowledge is understood by the young people.

Various forms of oral literature that relates to the environment were used to inculcate an apprehensive and conscious environmental mindset in the young people. Chitando (2017) notes that African children's literature is 
capable of equipping young people with the knowledge on sustainability that can aid in tackling the environmental crisis. Using two recorded oral stories in Charles Mugoshi book on Stories from a Shona Childhood (1999), Chitando highlights the importance of spirituality and practical actions on environmental issues such as climate change. The stories aver the need for a healthy relationship between the living and their environment as well as children being proactive and accountable in environmental issues. Similarly, Awuah-Nyamekye (2014) has shown how the Akan community in Nigeria used proverbs, folktales and riddles to create awareness amongst the youth.

A myth is narrated to Sengwer young people that relate to all aspects that hinge their worldview on the visible and the invisible world. In this myth, different clans have a variation with the bird that was used to deliver the information to the community. Some mention the crow whilst others mention the eagle. The myth mentions different aspects of the natural environment such as the bird and the hill, about how the hill eventually became a sacred legendary hill and how a particular bird became a totem to a certain clan (Mamati 2020):

A myth is told of how an eagle (some clans refer to it as crow) rescued the clan, during the community celebrations in the ancient time, an eagle came and warned the community about an impending danger that was to befall the community. The eagle acted as a messenger from God (Assis), but most people who were there didn't heed or listen to the eagle. The eagle approached one woman and told her the same message, the woman heeded the eagle's warning and fled immediately together with his family. After she left, the place where the celebration was taking place was engulfed with a large rock that fell from the sky and killed all those who did not heed the bird's message. This place would, later on, be Kiptaber legendary hill that is found in the southwest part of Cherangany hills. It is believed that the voices of those who were engulfed there could be heard during certain times of the year. (p. 300)

From this myth, young people are taught about the importance of heeding the advice of God (Assis), his agents, elders and parents. The myth encourages young people to be keener to occurrences in natural phenomena. Besides such a myth or stories, the Sengwer community uses other forms of oral literature such as songs, proverbs and riddles to transmit important ecological knowledge to young people. E. Kimaiyo (pers. comm., 30 June 2020) notes that the community has a special identity with bees and intrinsically they refer to themselves as 'people of bees'. They have riddles that relate to the bees. For example, Atinye tukchuu chimweke pich-sekem I have cows that sting people-bees. (Turung aret komos kusumyo. It is found beside our path - ground bees) (Kipatala, pers. comm., 23 November 2016).

The oral literature, with reference to various environmental resources, were used to communicate the importance of conserving the environment. Furthermore, the Sengwer people have established the Sengwer Cultural and Information
Centre (SCIC) and the traditional 'KopSengwer' houses at Kapolet to protect and preserve their culture and religious practices. Every year, they meet at this place for cultural events where community elders share the enigma tales of the community and the young people sing and dance to various songs that have environmental underpinnings (Mamati 2018:51). During these occasions, community elders instill environmental knowledge to the youth and the whole community at large. More importantly, they are made aware of the importance of the forest to their lives and the need to stay in harmony with God, Illat (chief divine agent of God), ancestral spirits and the natural environment.

\section{Implications for the future and the role of the media}

Through the experience of the Sengwer, it can be argued that African societies use different epistemological approaches to build up an environmental sentient youth. It is noted that, in the process of communicating their spirituality, most Kenyan societies worshipped and venerated everything below the earth, on the earth, between the earth and heaven and in the heavens (Gumo et al. 2012). Most African communities believed and taught young people that the environment was sacred as it is a habitat of the divinities, the spirits, the living dead and the ancestors. The natural environment hosts invisible beings that define the relationship between humans and nature, which is connected and is interdependent. Therefore, taboos, totems and religious beliefs provided an efficient framework for sustainable use of natural resources amongst the youth. Oral literature offered a good platform to communicate environmental knowledge.

Cohen and McIntyre (2019) have noted that Kenya has the most vibrant media landscape, in particular the thriving over 30 vernacular radio stations that broadcast their news, entertainment and carry out their programs through indigenous languages. Besides, there has been a growth of television stations that broadcast their programs in indigenous languages. Also, the media stations have a huge following on social media which can be leveraged to create environmental consciousness amongst the youth whose presence on social media cannot be ignored.

Many young people move to urban centres in search of employment. They coalesce around their tribemates, in particular estates which are the predominant settlement for a particular ethnic group (Wanjiru \& Matsubara 2017). Also, such a group of people would listen to their vernacular radio station and watch local television stations to feel connected to their ancestral roots and affirm their identity. The aforementioned can be tapped by urban migrants who hail from the same local ethnic communities to organise events of reconnecting with the indigenous traditions relating to the environment. Therefore, the media should be a useful agent to document, propagate and disseminate environmental knowledge. More importantly, these will nudge the whole population to be sentient of their surrounding environment as an inextricable part of their lives. 
Hamid et al. (2017) posit that social media can be repurposed as a tool to convey environmental sustainability awareness to students and staff in higher education. They point out the immense potential that universities have to create environmental sustainability awareness amongst the young generations. They advocate for a green education system, green curriculum, green syllabus and green practices. In a similar vein, the advocacy for a green sustainable lifestyle should not only be limited to higher institutions of learning but also all aspects of the daily lives of the people. For this to be achieved, many lessons can be drawn from diverse indigenous traditions that inculcated environment sustainability to young people by first shaping their worldview to be ecocentric. Young people who are proud of their culture can play a significant role in the fight against climate change and environmental issues. Most young people are technologically savvy, thus the need to repackage environmental knowledge into digital content to ensure that it is not forgotten, as well as making it appealing to young people (Gathogo 2013:11). The government, together with other stakeholders, should come up with relevant green educational and entertainment content that relates to the diverse local environmental and cultural context. The content can be shared on social media platforms such as YouTube, Facebook, Twitter, Instagram, TikTok, etc. Consequently, these will lead to a concerted effort to tackle the environmental crisis.

The potency of African religion that relates to ecology and the environment needs to be resuscitated and tapped in our engagements to create awareness and conserve the environment. For this to be achieved, there is a need for a change of approach by the government, religious organisations, world agencies and all civil movements to adopt a holistic approach that is cultural and context-based. Studley (2020) opines that it is important for 'foreigners' and 'outsiders' to understand and appreciate spiritual ecologies of the local population, for the incorporation of both human and non-human actors in conservation. He further avers for the creation of multiple worlds, epistemologies and ontologies instead of subordination to Western hegemony (Studley 2020:15). Likewise, churches should appropriate the Bible and constructively use it as a tool for eco-spirituality and a vital resource for decolonial engagement in environmental issues, as exemplified by Wangari Maathai's emphasis on holistic environmentalism through her writing and activism (Van Klinken 2021:7).

\section{Conclusions}

Contemporary ways of environment sensitisation and conservation are enshrouded in foreign frameworks that are not compatible with the diverse local contexts. With the new conservation models and approaches that have taken place in the last few decades, that sever indigenous peoples such as the Sengwer from their ancestral land, important ecological knowledge is on the verge of being obliterated. African environmental ethics rooted in religious systems motivated, sensitised, and instilled consciousness amongst people from a tender age to be concerned about the sacredness of the environment. The understanding of the environment from indigenous perspectives is fundamental in creating and designing programs that are well suited to a particular place. Such programs that take into consideration the religious and cultural setup make it easier for the youth to relate with. There is a need for a more conscious youth population who will be more concerned with their behaviour and actions towards the environment. To achieve this, it is essential to resuscitate useful context-based and culturally appropriate epistemological approaches to environmental sentiency as pointed out in this article.

\section{Acknowledgements}

We are deeply grateful to the study participants among the Sengwer people who graciously shared information. We are also thankful to Dr Simon Omare for the invaluable suggestions. We extend our indebtedness to the section editors of Youth, Faith and Environmental Consciousness, the editors of HTS, the anonymous peer reviewers and the AOSIS team for their invaluable work and suggestions.

\section{Competing interests}

The authors declare that they have no financial or personal relationships that may have inappropriately influenced them in writing this article.

\section{Authors' contributions}

K.M. contributed to conceptualisation, data collection and initial drafting of the manuscript. K.M. and L.M. both contributed to the analysis and interpretation of the data, critical revision of the manuscript, proofreading and the approval of the manuscript.

\section{Ethical considerations}

This article followed all ethical standards for research without direct contact with human or animal subjects.

\section{Funding information}

This research received no specific grant from any funding agency in the public, commercial or not-for-profit sectors.

\section{Data availability}

Data sharing is not applicable to this article as no new data were created or analysed in this study.

\section{Disclaimer}

The views and opinions expressed in this article are those of the authors and do not necessarily reflect the official policy or position of any affiliated agency of the authors.

\section{References}

Awuah-Nyamekye, S., 2014, 'Indigenous ways of creating environmental awareness: Case study from Berekum Traditional Area of Ghana', Journal for the Study of Religion, Nature and Culture 8(1), 46-63. https://doi.org/10.1558/jsrnc.v8i1.46 
Berkes, F., Colding, J. \& Folke, C., 2000, 'Rediscovery of traditional ecological knowledge as adaptive management', Ecological Applications 10(5), 1251-1262. https://doi.org/10.1890/1051-0761(2000)010[1251:ROTEKA]2.0.CO;2

Blackburn, R., 1970, A preliminary report of research on the Ogiek Tribe of Kenya, pp. 1-12, viewed 25 March 2021, from https://opendocs.ids.ac.uk/opendocs/handle $/ 20.500 .12413 / 441$ ?show=full.

Cavanagh, C.J., 2019, 'Dying races, deforestation and drought: The political ecology of social Darwinism in Kenya Colony's western highlands', Journal of Historical Geography 66, 93-103. https://doi.org/10.1016/j.jhg.2019.09.005

Chemhuru, M. \& Masaka, D., 2010, 'Taboos as sources of Shona peoples environmental ethics', Journal of Sustainable Development in Africa 12, 121-133, viewed 25 March 2021, from https://jsd-africa.com/Jsda/V12No7_Winter2010_A/PDF/Taboos $\% 20$ as $\% 20$ Sources $\% 20$ of $\% 20$ Shona $\% 20$ Peoples $\% 20$ Environmental $\% 20$ Ethics.pdf.

Chepkorir, M.K., 2016, Sengwer women's experience of evictions and their involvement in the struggle for Sengwer land rights, Forest Peoples Programme, Moreton-inMarsh, viewed 09 June 2021, from https://www.forestpeoples.org/sites/fpp/ files/publication/2016/10/sengwerwomenreportweb.pdf.

Chitando, A., 2017, 'African children's literature, spirituality, and climate change', The Ecumenical Review 69(3), 375-385. https://doi.org/10.1111/erev.12300

Cohen, M.S. \& Mclntyre, K., 2019, 'Local-language radio stations in Kenya: Helpful or harmful?', African Journalism Studies 40(3), 73-88. https://doi.org/10.1080/2374 harmful?', African Journ
3670.2020 .1729830

Crook, M. \& Short, D., 2020, 'Developmentalism and the Genocide-Ecocide Nexus', Journal of Genocide Research 2020, 1-27.

Diawuo, F. \& Issifu, A.K., 2018, 'Exploring the African traditional belief systems (totems and taboos) in natural resources conservation and management in Ghana', in J.O. Chimakonam (ed.), African philosophy and environmental conservation, Routledge, Abingdon.

Ezeanya-Esiobu, C., 2019, Indigenous knowledge and education in Africa, Springer Singapore.

Gathogo, J., 2013, 'Environmental management and African indigenous resources: Echoes from Mutira Mission, Kenya (1912-2012)', Studia Historiae Ecclesiasticae $39(2), 1-13$

Gumo, S., Gisege, S.O., Raballah, E. \& Ouma, C., 2012, 'Communicating African spirituality through ecology: Challenges and prospects for the 21st century', Religions 3(2), 523-543. https://doi.org/10.3390/rel3020523

Hamid, S., ljab, M.T., Sulaiman, H., Md. Anwar, R. \& Norman, A.A., 2017, 'Social media for environmental sustainability awareness in higher education', International Journal of Sustainability in Higher Education 18(4), 474-491. https://doi. org/10.1108/IJSHE-01-2015-0010

Kenya Land Commission, 1934, Report of the Kenya Land Commission, 1932-1933, Kenya National Archives, Nairobi.

Kenya National Archives (KNA), n.d., Safari file KNA/DC/TAMB/1/1/7, KNA, s.I.

Kenya National Assembly (PSC), 2012, Report of the parliamentary select committee on the resettlement of the internally displaced persons in Kenya, viewed 26 March 2021, from http://www.knchr.org/Portals/0/Reports/PSC_Final IDPs_report_2012-2.pdf.

Kenya National Bureau of Statistics (KNBS), 2019, 019 Kenya population and housing census volume I: Population by county and sub-county - Kenya National Bureau of Statistics, viewed 26 March 2021, from https://www.knbs. or.ke/?wpdmpro=2019-kenya-population-and-housing-census-volume-ipopulation-by-county-and-sub-county.

Kipkorir, B., 1976, 'The sun in Marakwet religious thought - A note', Journal of Eastern African Research \& Development 6(2), 175-178.

Kipkorir, B.E. \& Welbourn, F.B., 1973, The Marakwet of Kenya: A preliminary study, East African Literature Bureau, Nairobi.

Lee, K., Gjersoe, N., O'Neill, S. \& Barnett, J., 2020, 'Youth perceptions of climate change: A narrative synthesis', WIREs Climate Change 11(3), e641. https://doi. org/10.1002/wcc.641
Maathai, W., 2010, Replenishing the earth: Spiritual values for healing ourselves and the world, 1st edn., Doubleday, London and New York, NY.

Makamure, C. \& Chimininge, V., 2015, 'Totem, Taboos and sacred places: An analysis of Karanga people's environmental conservation and management practices', International Journal of Humanities and Social Science Invention 4(11), 7-12, viewed 25 March 2021, from http://www.ijhssi.org/papers/v4(11)/ 7-12, viewed 25 .

Mamati, K., 2018, 'An African religious worldview and the conservation of natural environmental resources: A case study of the Sengwer in Embobut Forest in Kenya', FERNS 1, 28-59, viewed 25 March 2021, from https://www. fernsjournal.com/uploads/1/0/6/0/106009621/mamati_an african. fernsjournal.com/upload
religious worldview.pdf.

Mamati, K.I., 2020, 'The Sengwer traditional religion and environment sustainability in Embobut Forest, Kenya', in M.C. Green \& M. Haron (eds.), Law, sustainability in Embobut Forest, Kenya, in M.C. Green \& M. Haron (eds.), Law,
religion and the environment in Africa, pp. 295-313. African Sun Media, religion and
Stellenbosch.

Maseno, L., 2020, 'An African response to Christopher Vena', in E.M. Conradie \& H.P. Koster (eds.), T\&T Clark handbook of Christian theology and climate changepp, pp. 336-339, T\&T Clark, London and New York, NY.

Mbiti, J.S., 1969, African religions \& philosophy, Heinemann, Oxford.

Mbiti, J.S., 1975, Introduction to African religion, Heinemann Educational, London.

Morara Mbuni, Y., Zhou, Y., Wang, S., Ngumbau, V.M., Mutuku Musili, P., Munyao Mutie, F. et al., 2019, 'An annotated checklist of vascular plants of Cherangan hills, Western Kenya', PhytoKeys 120, 1-90.

Ndlovu-Gatsheni, S.J., 2018, 'Metaphysical empire, linguicides and cultural imperialism', English Academy Review 35(2), 96-115. https://doi.org/10.1080/10 131752.2018.1530178

Nesterova, Y. \& Jackson, L., 2020, 'Indigenous perspectives on ecopedagogical literacy: The case of Taiwan', in M.A. Peters \& R. Heraud (eds.), Encyclopedia of educational innovation, pp. 1-6, Springer Singapore; Imprint: Springer, Singapore.

Orobator, A.E., 2008, Theology brewed in an African pot, Orbis Books, Maryknoll, NY.

Rowlands, M., 2005, 'Environmental epistemology', Ethics and the Environment 10(2), 5-27. https://doi.org/10.2979/ETE.2005.10.2.5

Semali, L. \& Kincheloe, J.L., 1999, What is indigenous knowledge?: Voices from the academy, L.M. Semali \& J.L. Kincheloe (eds.), Falmer, New York.

Studley, J., 2020, Indigenous sacred natural sites and spiritual governance: The lega case of juristic personhood, Routledge, London.

Thiong'o, N.w., 1986, Decolonising the mind: The politics of language in African literature / Ngũgĩ wa Thiong'o, Currey, London.

UNESCO, 2017, Local knowledge, global goals, pp. 1-46, viewed 26 March 2021, from http://www.unesco.org/new/fileadmin/MULTIMEDIA/HQ/SC/pdf/ILK_ex_ publication_E.pdf.

Van Klinken, A., 2021, 'Wangari Maathai's environmental Bible as an African Knowledge: Eco-spirituality, Christianity, and decolonial thought', Eastern African Literary and Cultural Studies 1-19. https://doi.org/10.1080/23277408.2 021.1922129

Wane, N.N., 2005, 'African indigenous knowledge: Claiming, writing, storing, and sharing the discourse', Journal of Thought 40(2), 27-46.

Wanjiru, M.W. \& Matsubara, K., 2017, 'Slum toponymy in Nairobi, Kenya', Urban and Regional Planning Review 4(0), 21-44. https://doi.org/10.14398/urpr.4.21

Wu, J., Snell, G. \& Samji, H., 2020, 'Climate anxiety in young people: A call to action', The Lancet Planetary Health 4(10), e435-e436. https://doi.org/10.1016/S25425196(20)30223-0

Yator, K., 2016, Safeguarding Sengwer territory, land, culture \& natural resources, viewed 04 April 2021, from http://www.iapad.org/wp-content/uploads/2016/01/ p3dm sengwer_people.pdf. 